\title{
上下方向の移動を伴う経路探索に関する研究 WAYFINDING IN CASES WITH VERTICAL TRAVELING
}

\author{
大野隆造*, 串山典子**, 添田昌志*** \\ Ryuzo OHNO, Noriko KUSHIYAMA and Masashi SOEDA
}

\begin{abstract}
This study intends to clarify the influence of vertical traveling on spatial cognition and to examine how wayfinding behavior varies with differences in individual strategies and environmental information. A series of wayfinding experiments was conducted in campus buildings and a department store, which were chosen in terms of visual information along the route and vertical floor alignment. Pointing task was also conducted in another building on the campus to examine individual orientational skills. Analyses of the results indicate that people tend to lose orientation after vertical traveling though some of them can recover it by obtaining environmental information, and that people tend to assume a new floor plan is similar to the former floor plan when they travel from one floor to another. It also revealed that using various information according to environment is essential for choosing right route.
\end{abstract}

\section{Keywords : Wayfinding, Vertical traveling, Visual information, Pointing task, Sketch map} 経路探索，上下方向移動，視覚的情報， 方向指示実験，スケッチマップ

\section{1. 研究の背景・目的}

近年, 複合的な大規模建築が増加している。このような建物では, 複数の階にわたって移動するうちに，自分の位置や目的地を見失うと いったことをしばしば体験する。階段やエレベータなどによる上下階 への移動は単に経路を長く複雑にするだけでなく，同一平面上におけ る連続的な移動とは異なる経路記憶の難しさがあると考えられる。 本研究の前提となる基本的な考え方として, 複数階にわたって移動 する場合, 経路は 3 次元的に連続して捉えられるのではなく，各階平 面上の経路が別々に記憶され，それらが階段などによる上下方向の移 動の地点で連結されていると考える。したがって，1つの階での経路 の終点と次の階の経路の始点とを結ぶ上下移動の際に上下階の平面が 正しく関係づけられないと迷うことになる。上 $2 つ の$ 階の平面が上 下移動の連結点を中心に回転したり，また，水平方向にずれて捉えら れたりすることが, 複数の階にわたる経路探索を困難にしていると考 える。

本研究は, 複数階にわたって建築空間内を移動する際に, 階段やエ レベータなどによる上下方向の移動が, 経路や方向の把握に与える影 響をについて実験的に確かめ, その際の経路探索行動が，個人や環境 条件によってどのように異なるのかを明らかにすることを目的とす る。

* 東京工業大学大学院綕合理工学研究科 教授. 工博

** 東烟建築設計事務所 工修

*** 東京工業大学大学院総合理工学研究科 大学院生 $\cdot$ 工修

\section{2. 既往の研究}

従来, 経路探索に関する研究は, 経路の平面形状と迷いの発生回数 との関係刘1,21や, サイン情報の密度や空間情報と経路探索行動との 関係を求めたもの文い,4などがあるが，それらはいずれも同一平面上 の経路探索行動や平面の形状を扱ったものである。複数階にわたる経 路探索行動を扱ったものとして, Passini ${ }^{\text {文 }}$ や日色文61 は, 商業施設 における経路探索行動のプロセスの記述を試みている。舟橋文は大

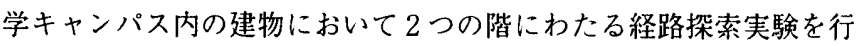
い，教示や経路の条件によっては階段が経路全体を把握する上での重 要な要素となり得ることを述べている。Montello文はは，複合施設に おいて異なる階の上下に重なり合った 2 経路を別々に学習させ，その 相互の位置関係の捉え方から，人の空間認知の過程を明らかにしてい る。しかしながら，階段やエレベータなどによる上下方向の移動自体 が方向や位置の把握にどのような影響を与え, その結果として経路探 索行動がどのように変化するかについて考察した研究は見られない。

\section{3. 研究の方法}

本研究では，建築の内部空間において，大学生男女各 8 名計 16 名 の被験者を用いて方向指示実験および経路探索行動実験を行う。実験 場所としては，経路の把握および探索行動に影響を及は寸と考えられ 
表 1 実験場所の諸条件 ‘( $(\bigcirc$ : 有, $\times$ : 無)

\begin{tabular}{|c|c|c|c|c|c|}
\hline \multirow[t]{2}{*}{ 実験場所 } & \multirow{2}{*}{$\begin{array}{l}\text { 視覚的 } \\
\text { 情報量 }\end{array}$} & \multirow{2}{*}{$\begin{array}{l}\text { 上下階の } \\
\text { 経路平面 }\end{array}$} & \multicolumn{3}{|c|}{ 上下方向の移動手段 } \\
\hline & & & 随段 & エレベータ & エスカレータ \\
\hline - 東京工業大学本館 & 少 & 同 & 0 & $x$ & $x$ \\
\hline - 東京工業大学石川台実験棟 & 少 & 異 & 0 & $x$ & $x$ \\
\hline - 東京大学法文 2 号館 & 少 & 同 & 0 & 0 & $x$ \\
\hline - T百賀店 & 多 & 间 & 0 & 0 & 0 \\
\hline
\end{tabular}

る環境条件である，「経路周辺の視覚的情報量」「上下階の経路平面 の対応」「「上下方向の移動手段」の 3 点に着目し, 表 1 に示す 4 箇所 を選定した。経路周辺の視覚的情報量が少ない建物としては，床や壁 面等の仕上げも均一で，サインとしては各室の室名表示板のみである 大学キャンパス内の建物を選定した。一方, 視覚的情報量が多い建物 としては，多様な仕上げの床や壁面，方向案内板などのサイン，さら には陳列された商品や広告などにより，多くの梘覚的情報が提供され ている百貨店を選定した。上下方向の移動手段としては，そこにおけ る身体運動など移動の形態が異なる，階段，エレベータ，エスカレー タの 3 種類を設定した淮2)。

\section{4. 方向指示実験}

\section{4-1 実験の目的と方法}

上下方向の移動に伴う方向感の亦失の傾向を調べることを目的と し，東京工業大学本館の折り返し階段を途中に含む実験経路 (図 1) において方向指示実験を行った。実験は，出発点において被験者自身 に目印を置かせた後，実験経路を実験者に先導されながら途中の 3 地 点において，方位磁針を模した方向指示板の矢印を回転させることに より，出発点に置いた目印の方向を指示させるという手順で行った。 方向を指示させる 3 地点はそれぞれ，同一平面のみの移動で上下方向 の移動の影響を受けない地点 I, 階段による上下方向の移動後の地点 || 洁3)，その後さらに1回の曲折を経た地点 IIである。地点 I， || は それぞれ空のない廊下にあり，地点川は，右側および正面突き当たり に悹のある廊下にある。

\section{4-2 結果と考察}

方向指示実験の結果を正しい方向とのずれの大きさに応じて，士 $25^{\circ}$ 以内のものを「正確」， $\pm 50^{\circ}$ 以内のものを「おおむね正確」，そ れ以上ずれているものを「誤りり 3 段階に評洒したi゙4。 Kozlowski 文ッやLawton文101 はこのような方向指示実験の結果が個人の方向感 覚と関係があることを示しておう，個人の方向を把握する能力を調べ るうえでもこの実験は有効であると考え，被験者をその成績に基づき 表 2 のように分類した。

グループ A は全ての地点において正確な方向を指示した被験者 7 名であり，これらの被験者は同一平面内の移動だけでなく：上下方向 の移動がある場合でも，正確な方向を保持し続ける能力があるといえ る。グループBの 2 名は地点 |において正しい方向から $50^{\circ}$ 程度ず れた方向を指示した後，地点川，川ににおてともに地点、で指示した 方向を正確に指示した。このことはこれらの被験者が地点ににおいて 目印の方向を尋ねられることによって初めて方向について意識し，そ こで自身が指示した方向を正しい方向であるとみなしたことが，その 後の結果に影響したものと考えられる。グループCの被験者 4 名は, 地点 |においてはおおむね正確な方向を指示しているものの，地点川 においては誤った方向を指示している。これらの被験者は, 同一階内

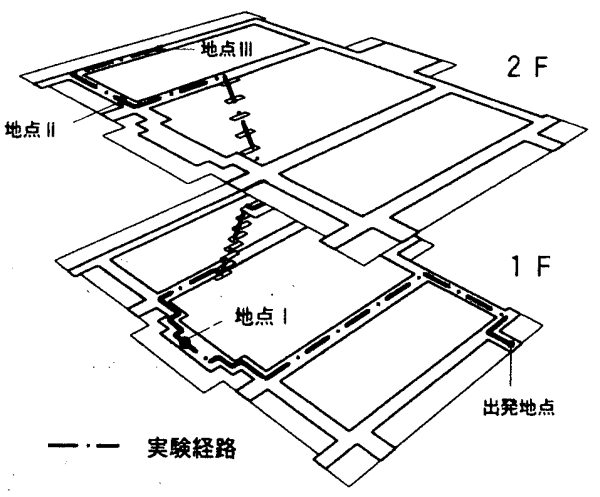

図 1 方向指示実験経路（東京工業大学本館）

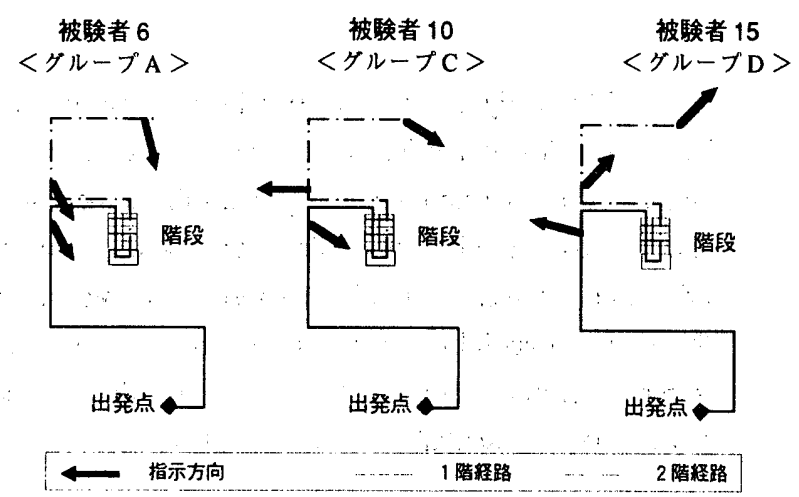

図 2 方向指示実験の結果例

の移動時にはある程度方向を把握できていたが，階段による上下方向 の移動によって方向を見失なったといえる。しかし，その後地点川に おいては再びおおむね正確な方向を指示している。これは,これらの 被験者が, 地点川から地点㸪への移動途中や地点川において，㝕の外 の景色など周辺環境から何らかの情報を得ることにより，再び正しい 方向を把握することができた為であると考えられる。グループDの被 験者 3 名については，同一階内のみの移動である地点|の時点で既に 誤った方向を指示しており，方向を保持することが不得手で，また，

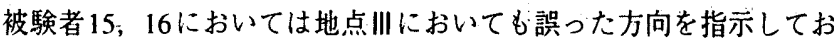
り，これらの人は環境から情報を得て正しい方向を再認識することも できないといえる。

以上より，経路移動時にどの程度正しく方向を把握できるかは個人 にようで異なっているが，上下方向の移動によって方向を見失う傾向 が見られ，迷いの原因の一つとなりうることが示された。しかし，一 度方向を見失った場合でも，周辺環境から情報を得ることにより再び 正しい方向を再認識できるという場合があることが明らかになった。

\section{5. 上下の経路平面の異なる空間での経路探索}

5-1 実験の目的と方法

複数階にわたる移動時に上下の階での位置の空間的対応をどの程度 正しく把握できるのかを検証することを目的として，上下階で経路平 面が異なる東京工業大学石川台実験棟において経路探索行動実験を 行った。図 3 に示すようにこの建物は 1 階部分は中央直廊下， $2 \cdot 3$ 階部分はループ上の中廊下で，いずれの廊下にも空はない。実験手順 は，折り返し階段を途中に含む 2 経路 $(1 \mathrm{~F} \rightarrow 2 \mathrm{~F}, 1 \mathrm{~F} \rightarrow 3 \mathrm{~F})$ に おいてそれぞれ，被験者を出発地点から目的地点（地点イ，口)へと 
表 2 被験者別実験結果

\begin{tabular}{|c|c|c|c|c|c|c|c|c|c|c|c|c|c|}
\hline \multirow{3}{*}{$\begin{array}{l}\text { グ } \\
ル \\
1 \\
7\end{array}$} & \multirow{3}{*}{$\begin{array}{l}\text { 被 } \\
\text { 駚 } \\
\text { 者 }\end{array}$} & \multirow{2}{*}{\multicolumn{3}{|c|}{$\begin{array}{c}\text { 方向指示実験 } \\
\text { (東京工業大学本館) }\end{array}$}} & \multirow{3}{*}{$\begin{array}{c}\text { 石川台 } \\
\text { 実験棟 } \\
\begin{array}{c}\text { スケッチ } \\
\text { マップ }\end{array} \\
\end{array}$} & \multirow{2}{*}{\multicolumn{2}{|c|}{ 東京大学法文 2 号館 }} & \multicolumn{6}{|c|}{ T百貨店 } \\
\hline & & & & & & & & \multicolumn{4}{|c|}{ 経路選択理由 } & \multicolumn{2}{|c|}{ 経路探索行動 } \\
\hline & & 地点 I & 地点 II & 地点 III & & $\begin{array}{l}\text { スケッチマッフ } \\
\text { の間挐いの特徽 } \\
\end{array}$ & \begin{tabular}{|c} 
経路探索 \\
行動 \\
\end{tabular} & 方向 & $\begin{array}{l}\text { 空闈的 } \\
\text { 特徵 }\end{array}$ & $\begin{array}{l}\text { 表面的 } \\
\text { 特徵 } \\
\end{array}$ & $\begin{array}{l}\text { 要秦的 } \\
\text { 特徽 }\end{array}$ & 「誤り」 & 「迷い] \\
\hline \multirow{7}{*}{ A } & 1 & $\mathrm{O}$ & 0 & 0 & & & & & & & & 0 & 0 \\
\hline & 2 & 0 & O & O & 重积合わ世 & & & & & & & 0 & 0 \\
\hline & 3 & 0 & 0 & 0 & 重敉合わ世 & 父落 & 誤り & & & & & 0 & 0 \\
\hline & 4 & 0 & O & 0 & & 曲拆道 & & & & & & 0 & 2 \\
\hline & 5 & O & 0 & 0 & 重初合わせ & 順序裐 り & 誤り & & & & & 0 & 6 \\
\hline & 6 & $\mathrm{O}$ & 0 & $\mathrm{O}$ & & & & & & & & 1 & 2 \\
\hline & 7 & $\mathrm{O}$ & 0 & $\mathrm{O}$ & 重秝合わせ & & & & & & & 1 & 3 \\
\hline \multirow[t]{2}{*}{ B } & 8 & $\Delta$ & $\Delta$ & $\Delta$ & & & & & & & & 0 & 3 \\
\hline & 9 & $\Delta$ & $\Delta$ & $\Delta$ & 重权合わ世 & & & & & & & 2 & 6 \\
\hline \multirow{4}{*}{ C } & 10 & $\triangle$ & $x$ & $\Delta$ & 重ね合わせ & 栥落 & & & & & & 1 & 1 \\
\hline & 11 & $\Delta$ & $x$ & 0 & 重权合わ世 & & 迷い & & & & & 1 & 4 \\
\hline & 12 & $\Delta$ & $x$ & $\Delta$ & 重权合わせ & & & & & & & 1 & 5 \\
\hline & 13 & $\Delta$ & $x$ & 0 & 曲折逆 & 曲折逆 & & & & & & 3 & 6 \\
\hline \multirow{3}{*}{$D$} & 14 & $x$ & $x$ & $\Delta$ & & マップが描けない & & & & & & 1 & 3 \\
\hline & 15 & $x$ & $x$ & $x$ & 曲折逆 & 欠落 & 誤り & & & & & 1 & 6 \\
\hline & 16 & $x$ & $x$ & $x$ & 重机合わせ & & 迷い & & & & & 2 & 5 \\
\hline
\end{tabular}

方向指示実験の結果

○正確

$\triangle$ おおむね正確

$\times$ 誤り

\section{スケッチマップの結果}

「曲折逆」左有の曲折を逆 に描いたもの

「久落」途中の曲折点が 欠落したもの

「順序䛊り」前後の曲折点 の順忬が入机替 わったもの

\section{経路選択理由に挙げられた回数}

3 同以:

201

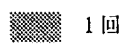
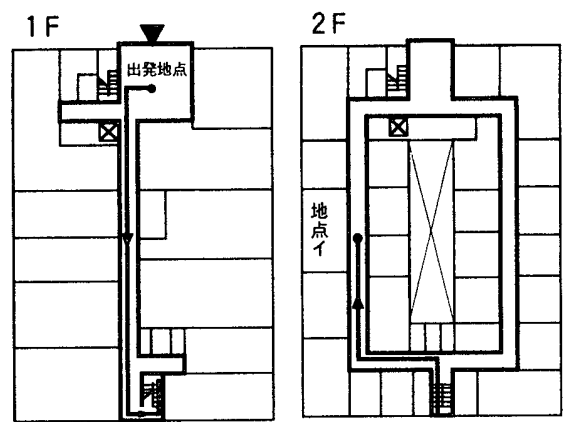

$3 \mathrm{~F}$

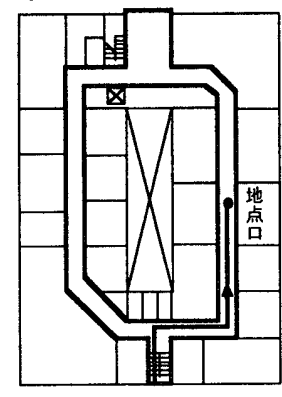

図 3 東京工業大学石川台実験棟平面図

$1 \mathrm{~F}$

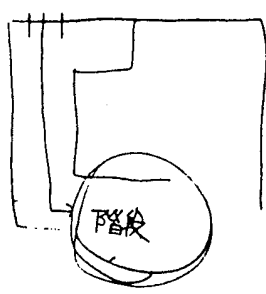

$2 \mathrm{~F}$

$3 \mathrm{~F}$
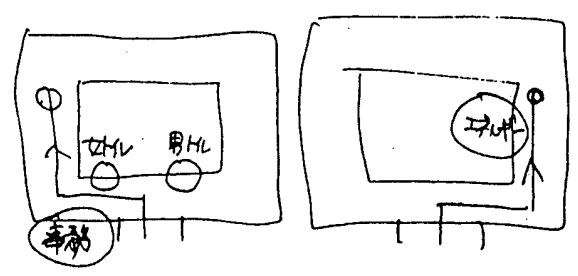

図4 スケッチマップの例

誘導し，そこで仮の課題 (歩行にかかる時間の測定)を与え独力で出 発地点に戻らせ (試行 1 ) た後, さらに出発地点から目的地点へと独 力で向かわせる (試行 2 ) というものである。実験の最後には $2 つ 0$ 経路のスケッチマップを描かせる。

\section{5-2 結果と考察}

経路探索行動そのものについては, 実験経路が短く, 経路を選択す べき地点も 1 箇所と少なかったため 1 人を除き全ての被験者が正しい 経路を選択し，迷い行動もほとんど見られなかった。しかし，被験者 が描いたスケッチマップからは興味深い結果が得られた。それは, 実
表 3 経路選択理由に挙げられた要素の分類

\begin{tabular}{|c|c|c|}
\hline & 分類 & 被験者が挙げた経路選択理由（例） \\
\hline \multirow{4}{*}{ 環境的な情報 } & 方向 & あっ七の方，直の方 \\
\hline & 空間的な特徵 & 湾曲した榔下，火来竞，階段，䨌用気 \\
\hline & 表面的な特徽 & 森の色，天非の件:はド \\
\hline & 要素的な特徵 & C.Do)文子，ブーツ，子倛服志り坋 \\
\hline
\end{tabular}

験経路が 1 階部分と $2 ， 3$ 階部分とでは上下で異なっているにもかか わらず，半数以上の被験者（16人中 9 人，表 2 参照）が, それらの 経路が重なっているようなスケッチマップ（図 4) を描いたのであ る。そして，そのようなスケッチマップの大半は，階段部分について， 実際とは異なる形状にしたり，曲折や長さを曖昧に描くことにより， 上下階で経路が重なり合うようにしていた。つまり，上下移動の部分 で平面的な位置のずれを調整していたことになる。これより，複数階 にわたる移動時においては，上下階の経路の空間的対応が把握されに くく,多くの人は実際の空間の違いにも関わらず，「上下階の平面は 同じで重なり合っている」という先入観に基づいて，先に体験した経 路のイメージから次の階の空間を理解する傾向があるといえる。

\section{6. 上下方向の移動手段の違いと経路探索行動}

\section{6-1 実験の目的と方法}

上下方向の移動手段および経路周辺の視覚的情報量の違いによる経 路探索行動の変化を検証することを目的として, 東京大学法文 2 号館 およびT百貨店において $2 つ の$ 階にわたる実験経路を設定し経路探索 行動実験を行った。

東京大学法文 2 号館においては，異なる上下方向の移動手段を各々 含んだ, エレベーター経路 $(1 \mathrm{~F} \rightarrow 3 \mathrm{~F})$, 変形階段経路 $(3 \mathrm{~F} \rightarrow 4 \mathrm{~F})$, 折り返し階段経路 $(1 \mathrm{~F} \rightarrow 2 \mathrm{~F})$ の 3 本の実験経路を設定した。実験 手順は, それぞれの経路について, 出発地点から目的地点まで被験者 を誘導し，そこで仮の課題 (簡単な選択回答式のクイズ)を与え, 選 択肢が用意してある出発地点まで独力で戻らせ (試行 1), 選択回答 
2 F

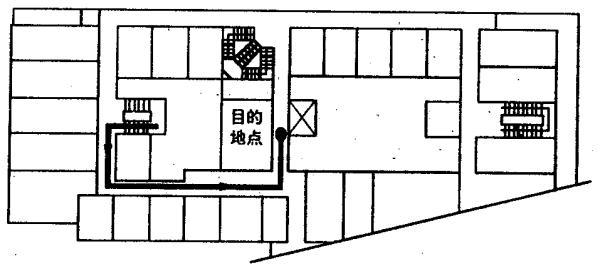

$1 \mathrm{~F}$

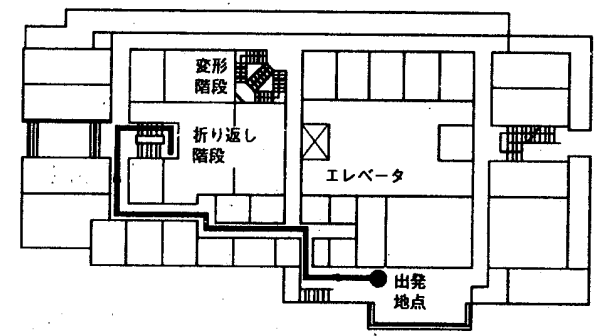

図 5 東京大学法文 2 号館平面図（折り返し階段経路）

$6 \mathrm{~F}$

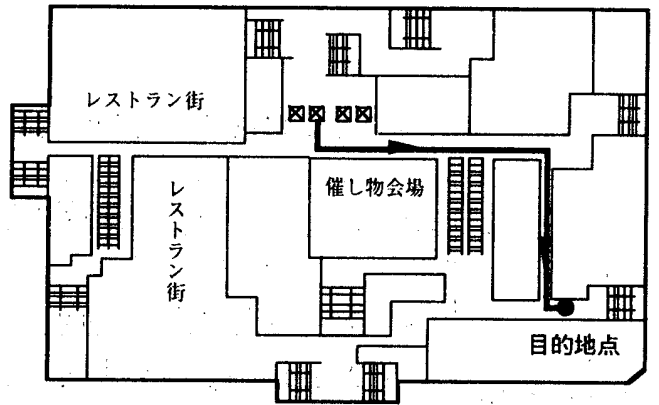

$4 \mathrm{~F}$

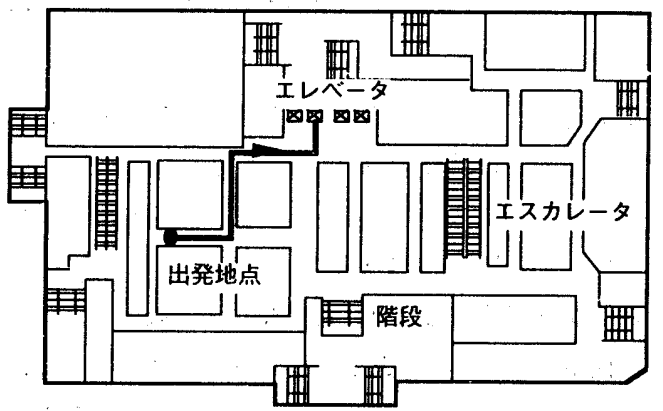

図 6、T百俥店平面図（エレベータ経路）

後再度目的地点まで独力で歩行させる（試行 2 ）というものである。 3 経路のうち最後に行うた折り返し階段を含む経路については, 独力 で出発地点に戻った時点で (試行 1 終了後), 被験者に経路のスケッ チマップを描かせ，その後再度目的地点まで独力で向かわせた。

T百貨店に於ては，エレベータを含む経路 $(4 \mathrm{~F} \rightarrow 6 \mathrm{~F})$ ，エスカレー 夕を含む経路 $(1 \mathrm{~F} \rightarrow \mathrm{B} 1 \mathrm{~F})$ ，同じ折り返し階段を含み，階段取り 付き部の通路の作られ方が異なる 2 経路 $(1 \mathrm{~F} \rightarrow 2 \mathrm{~F}, 5 \mathrm{~F} \rightarrow 4 \mathrm{~F})$ の 計 4 経路を設定した。実験は, 仮の課題(商品の選定)を与え東京大 学の場合と同様に行い, 経路探索実験終了後には各々の経路の経路選 択地点に再度戻り，被験者に経路選択の理由をインタビューした。 6-2 結果と考察

本実験では経路探索時の被験者の行動を周囲を見回したり立ち止っ たりする「迷い」行動と，誤った経路を選択して進む「誤り」行動に 分け分析した。図 7 は, 各実験経路の上下方向の移動直後の経路選択 地点注5!における「迷い」と「誤り」の発生回数を示したものである。
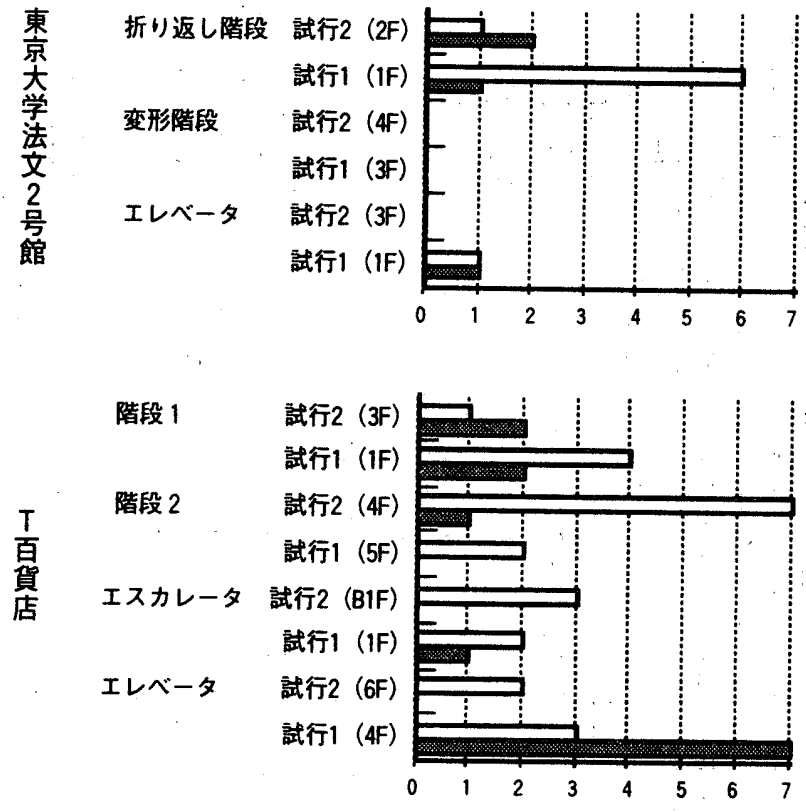

図7各実験経路における 「迷い」、「誤り」発生回数

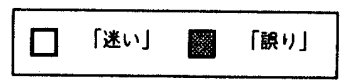

上下方向の移動手段の違いについてみると，上下方向の移動部分に 回転運動を伴わないエスカレータは他の移動手段に比べて「迷いやや 「誤り」が少ないとした当初の予想に反して，移動手段の違いによっ て説明できるような明確な関係は見られず，同じ移動手段であって も, 東京大学の折り返し階段経路やT百貨店のエレベータ経路のよう に, 経路選択地点によって「迷い」や「誤り」の発生回数に大きな差 のある場合がある。

T百貨店のエレベー夕課題試行 2 (4階)の選択地点においては「誤 り」の発生回数が全課題の中で最も多くなっている。この原因として は，選択地点から見渡せる床や天井の仕上げが均一で，明確な目印と なるようなサインや商品がないなど, 選択地点における左右のシーン が似通っていることが考えられる。また，梘覚的な情報により経路を 特定できない状況では, 自らの方向感に頼ることが考えられるが, こ の場合は目的地点から出発地点に戻る課題であるために，先に実験者 に先導された際に体験した経路を逆向きに進む必要があり，身体回転 など方向に関する記憶が混乱しやすいことも挙げられる。これに対 し, 同じT百貨店のエレベー夕試行 1 課題では,「誤り」や「迷い」が 少ない。これは, 選択地点の右方向がレストラン街で通路上にそれを 示す大きなサインがあり，また床や天井の仕上げも異なっているのに 対して, 左方向は催し物会場でお歳暮用の商品が山積みされており, 要素的, 空間的情報が左右で明確に異なっていたことが原因と考えら れる。東京大学のエレベータ経路においても「誤り」や「迷い」が少 なく，これも壁面と忩によって選択点の左右で明るさや外の景色が明 確に異なっていたためであると考えられる。

この他の東京大学折り返し階段経路についても経路選択点での左右 の見えの違いが「迷い」や「誤り」の発生回数と関係していることが 確認された洁6。以上から，上下方向の移動手段の違いによる影響は， 他の環境条件による影響に比べて小さく，上下移動直後(階段の取り 付き部など）の空間の作られ方が「迷い」や「誤り」の発生に大きく 影響を及ほしていることが明らかになった。 


\section{7. 経路探索行動の個人差に関する考察}

\section{7-1 スケッチマップと経路探索行動の関係}

東京大学法文 2 号館の折り返し階段経路について被験者が描いたス ケッチマップマップと描画後の経路探索行動とを比較すると(表 2), マップを描けなかったり間違えてたりしているにもかかわらず正しい 経路を選択している被験者（4，10，13，14）がいることが分かる。 これは，事前に方向などの経路に関する情報が十分に把握されていな くても，その場その場で周辺環境から情報を得ることにより正しい経 路を選択できるということを示している。その一方で, 被験者 14 の ように，方向指示実験において全地点で誤った方向を指示し，経路探 索実験でも正しい経路選択ができないなど，事前に方向を認識するこ とも，実際の場面において情報を得ることもできない人が存在するこ とから，必ずしも全ての人が眼前の環境から情報を得て経路選択のた めにうまく利用できるとは限らない。

\section{7-2 経路選択理由と経路探索行動の関係}

T百貨店において被験者が経路選択の理由として挙げた回答につい てその内容に基づいて表 3 のように分類した。「方向」は被験者が 「あっちの方向」「左手」などといった自己を中心とするエゴセント リックな系でのおおよその方向を捉えたものであり，このような記憶 には視覚的な情報だけでなく，身体運動的な記憶も含んでいると考え られる文5)。「空間的な特徴」は廊下の形状や奥行きなど 3 次元的な空 間の作られ方に基づくものであり，「表面的特徽」は床や天井の仕上 げといった 2 次元的な特徽によるもの，「要素的特徴」はサインや商 品などの注視対象となり得る要素的な情報である。

それぞれの被験者が経路選択理由として挙げた内容の種類別の回数 と経路探索の際の「迷い」と「譟り」の回数を表 2 の右端に示す。こ れによると，「迷い」や「誤り」の回数が中間的な被験者については あまり明確ではないが，「迷い」や「誤り」の全くない被験者は，方 向指示実験の成績が良く，経路選択の理由として「方向」や「空間的 な特徵」を数多く挙げるなど，幅広い種類の情報を経路選択のために 利用していることが分かる。一方，「迷い」や「誤り」が多い被験者 については，経路選択に用いた情報がサインや商品などの要素的な情 報に偏って扝り，方向指示実験の成績が悪く，「方向」に関する情報 については殆ど挙げられていないことが分かる。また，「空間的な特 徽」についても挙げられていない場合が多い。つまり，これらの被験 者は, 前述したエ、レベー夕課題試行 2 の 6 階の選択地点のように, 明 確に経路を特定できる要素的情報がある場合にはそれによって正しい 経路を選択できるが，エレベー夕課題試行 1 の 4 階の選択地点のよう にそのような情報がない場合には，それに変わる経路選択のための情 報として自身の方向感覚や空間的な特徴などをうまく利用できないた め，結果として迷ったり，誤った経路を選択する場合があることを示 している。したがって, 正しい経路選択を行うためには「環境の変化 に応じて異なる種類の情報を柔軟に組み合わせて利用する」叫こと が有効であることが確かめられたが，それができるかどうかは個人に よって大きく異なることが明らかになった。

\section{8. まとめ}

本研究では，以下のことが明らかになった。

1. 方向の把握や正しい経路を選択する能力には大きな個人差がある。

2.上下方向の移動によりそれまで捉えられていた方向を見失った場
合でも，周辺環境から情報を得ることで正しい方向や経路を再認識で きることがあるが，それは個人や環境のあり方によって異なる。

3. 複数の階にわたって移動する場合，人は「上下階の平面は同じで 重なり合っている」という先入観に基づき, 先に体験した経路のイ メージによって次の階の空間を理解する傾向がある。

4. 上下方向の移動手段の違いによる影響は移動後の階の環境から提 供される情報の違いによる影響に比べて小さい。

5. 正しい経路を選択するためには異なる種類の情報を周辺環境の変 化に応じて柔軟に組み合わせて利用することが有効である。

注

1）本論文は1997年度建筑学会大会で発表した内签（文献12）に加筆・修正しし たものである。

2 ) 実験経路の設定にあたっては, 出発地点から日的地点まで不自然な大回り を避けできるだけ最知距嚾になるようにし，また教示では仮の課題を与え て，日常行方経路探装行動により近くなるよう心脚けた。

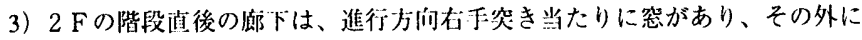

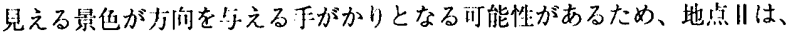
度曲折を経た空の見えない榔下上の地点とした。

4）方问指示実駼の結果の判定については、実験経路における曲折が各々 $90^{\circ}$ であることから、これを基準に考之、才问を指示する際の䛇差として土5

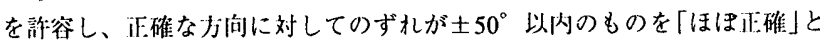
判定した。また、その半分の $\pm 25^{\circ}$ 以内のものを「正確」とした。こ札は、

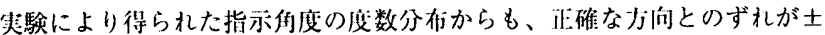
$50^{\circ}$ 以内のものとそ朾上ずれているものとで分有が分かれており、妥当な 判定基潅であると考えられる。

5）间じ垁験経路においても武行 1 と試行 2 ではに下方向移動直後の経路選択

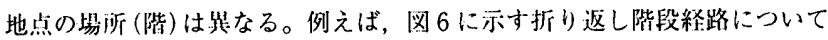
見ると，陚行1における経路選护地点は 1 階の階段を下りた阳後の地点であ り，武行 2 においては 2 階の階段をたった防後の地点になる。

6）東京大学折り这し階段稀路では、试行 1 の1階の階段を下りた地点におい

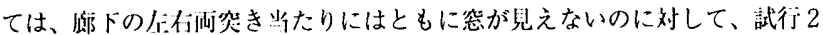
の 2 階の階段をにった地点においては、们乎突き当たりに空が光えるが、今

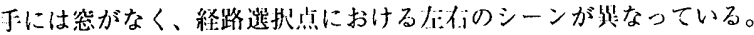

\section{参考文献}

1) Weisman, J. : Evaluating architectual legibility ; Way-Finding in the built e nvironment, Environment and Behavior, Vol13, pp 189-204, 1981

2 ) O'Neill, M. J. : Effects of Familiality and Plan Complexity on Wayfinding in Simulated Buildings, Journal of Environmental Psychology, No.12, pp.319-327, 1992

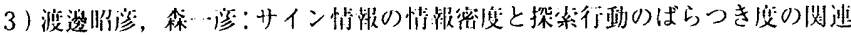

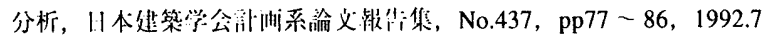

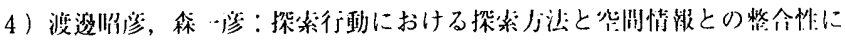

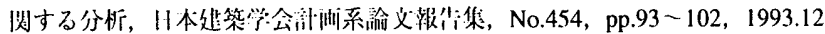

5 ) Passini, R. : Wayfinding in Architecture, Van Nostrand Rheinhold, 1984

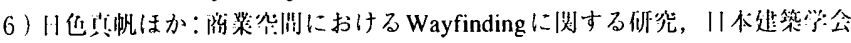

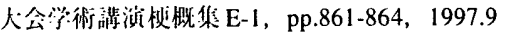

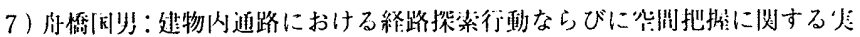

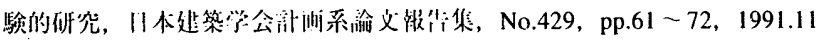

8 ) Montello, D. R., Pick, H.L. : Integrating knowledge of vertically aligned largescale spaces, Environment and Behavior, Vol.25, No.4, pp.457-484, 1993.7

9 ) Kozlowsky, L. T. \& Bryant, K. J. : Sence of Direction, spatial orientation and cognitive maps, Journal of Experimental Psychology: Human Perception and Performance, 3, pp.590-598, 1977

10) Lawton, C.A. : Strategies for indoor wayfinding ; the role of orientation, Journal of Environmental Psychology, No.16, pp.137-145, 1996

11) Heft, $\mathrm{H}:$ The role of environmental features in route-learning: two expanatory $\mathrm{s}$ tudies of wayfinding, Environmental Psychology and Non-verbal Behavior, 3, pp.172-185, 1979

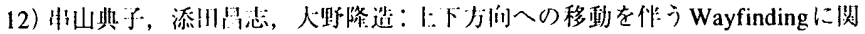

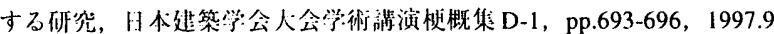

（1998年 4 月10日原稿受理，1998年 9 月11日採用決定） 